\begin{tabular}{r|l|l|l}
$\begin{array}{c}\text { Case Reports in } \\
\text { Oncology }\end{array}$ & $\begin{array}{l}\text { Case Rep Oncol 2011;4:143-148 } \\
\text { DOl: 10.1159/000326801 }\end{array}$ & $\begin{array}{l}\text { Published online: } \\
\text { March 16, 2011 }\end{array}$ & $\begin{array}{l}\text { O 2011 S. Karger AG, Basel } \\
\text { ISSN 1662-6575 } \\
\text { www.karger.com/cro }\end{array}$ \\
\hline
\end{tabular}

\title{
Thrombotic Thrombocytopenic Purpura and Gemcitabine
}

\author{
Pashtoon Murtaza Kasi \\ International Scholars Program, Department of Medicine, University of Pittsburgh \\ Medical Center, Pittsburgh, Pa., USA
}

\section{Key Words}

Thrombotic thrombocytopenic purpura - Gemcitabine - Non-small cell lung cancer .

\begin{abstract}
Thrombotic thrombocytopenic purpura (TTP) is a rare and life-threatening complication of gemcitabine treatment. Since the approval of this nucleoside analog for the treatment of pancreatic cancer by the FDA in 1996, reported incidence varies from 0.015 to $1.4 \%$. The classic 'pentad' describing the disease process (fever, hemolytic anemia, thrombocytopenia, neurological complications and renal impairment) is not always present to the same extent in every patient. Here, we present a rare case of TTP associated specifically with gemcitabine treatment, and further, we briefly discuss the manifestations, treatment options and outcomes related to the complication. In our opinion, it is important to realize that as the indications for the use of gemcitabine increase and its use becomes more widespread, TTP and other disorders on the spectrum of thrombotic microangiopathies are important considerations to remember in patients with worsening anemia and thrombocytopenia. New onset or exacerbation of underlying hypertension may provide a clue to diagnose the disease entity earlier in this subgroup of patients.
\end{abstract}

\section{Background}

Thrombotic thrombocytopenic purpura (TTP) is a rare but life-threatening condition with significant morbidity and mortality associated with the disease [1]. Prior to the 1960s, the mortality numbers reporting TTP were as high as 77\% [2]. The classic 'pentad' describing the disease process (fever, hemolytic anemia, thrombocytopenia, neurological complications and renal impairment) is not always present to the same extent in every patient. Of the causes associated with TTP, drugs, especially chemotherapeutic agents, are one of them. Early identification of TTP in such circumstances is essential in improving survival and instituting early treatment. Here, we present a rare case of TTP associated specifically with gemcitabine treatment, and further, we briefly discuss the manifestations, treatment options and outcomes related to the complication. 


\begin{tabular}{c|l|l|l}
$\begin{array}{c}\text { Case Reports in } \\
\text { Oncology }\end{array}$ & $\begin{array}{l}\text { Case Rep Oncol 2011;4:143-148 } \\
\text { DOI: 10.1159/000326801 }\end{array}$ & $\begin{array}{l}\text { Published online: } \\
\text { March 16, 2011 }\end{array}$ & $\begin{array}{l}\text { O 2011 S. Karger AG, Basel } \\
\text { ISSN 1662-6575 } \\
\text { www.karger.com/cro }\end{array}$ \\
\hline
\end{tabular}

\section{Case Report}

A 68-year-old woman with a past medical history significant for stage IIIB non-small cell lung cancer diagnosed 2 years ago presented to the Emergency Department with complaints of fever and headache 3 days after receiving a cycle of chemotherapy.

With respect to her oncological history, she was originally treated with carboplatin, taxol (paclitaxel) and avastin (bevacizumab). In 2009, she showed progression of disease and was started on tarceva (erlotinib), and then switched to Alimta. However, following 8 cycles of Alimta (pemetrexed), a followup computed tomography (CT) scan showed progression of disease, which is being treated with gemcitabine (Gemzar) since July 2010, showing no major complications and a stable malignancy.

Apparently, after the cycles of chemotherapy, she used to have mild headaches and occasionally fever lasting for one or two days; however, symptoms related to her last cycle of chemotherapy 3 days ago were different. She described the pain as diffuse, sudden in onset, aching in nature and as the 'worst' headache she had ever had. Associated symptoms included fever $\left(38.4^{\circ} \mathrm{C}, 101.1^{\circ} \mathrm{F}\right)$ on presentation, some neck pain/stiffness and eye discomfort/photophobia. Her vital signs otherwise were stable on presentation except for a systolic and diastolic blood pressure of 145-185 and 75-94 mm Hg, respectively. Of note, the patient was not hypertensive prior to admission and her only medical problems were mild depression and cervical cancer for which she had undergone curative surgery 40 years ago.

Initially, suspecting a possible viral versus bacterial meningitis, a lumbar puncture was instantly performed. However, the results were not suggestive of meningitis, and CSF parameters were within normal limits. The patient's hemoglobin/hematocrit levels were noted to have trended down from a baseline of $9.3 \mathrm{~g} / \mathrm{dl}(28.5 \%)$ to $8.4 \mathrm{~g} / \mathrm{dl}(25.8 \%)$. Thrombocytopenia worsened from $144 \times 10^{9} / 1$ on presentation to $107 \times 10^{9} / 1$ on day 2 of admission.

A literature review of side effects associated with gemcitabine showed that gemcitabine has the potential, though rarely, to cause microvascular angiopathy leading to hemolytic uremic syndrome (HUS), TTP, malignant hypertension and other related diseases.

Given concerns for hemolysis and possible TTP in our patient, a peripheral smear was examined, which did show presence of schistocytes. Hemolysis laboratories also confirmed intravascular hemolysis (a high LDH of $437 \mathrm{IU} / \mathrm{l}$ and haptoglobin $<4 \mathrm{mg} / \mathrm{dl}$ ), for which the hematology department was promptly consulted. The patient was urgently started on plasmapheresis the same day and is undergoing daily plasmapheresis with monitoring of $\mathrm{LDH}$, haptoglobin, hemoglobin, hematocrit and platelet counts along with her renal function. Table 1 highlights some of the typical findings reported in patients with gemcitabine-associated TTP and the findings seen in our patient.

\section{Discussion}

TTP is a rare and life-threatening complication of gemcitabine treatment. Since the approval of this nucleoside analog for the treatment of pancreatic cancer by the FDA in 1996, reported incidence varies from 0.015 to $1.4 \%$ [3]. Endothelial cell injury is thought to be the postulated mechanism behind gemcitabine-induced TTP. The downstream effects from the endothelial dysfunction, including release of nitric oxide and von Willebrand factor, and increased levels of tissue plasminogen activator, thrombomodulin, and plasminogen activator inhibitor, are described to promote the development of TTP [4]. With the use of this drug becoming more common, gemcitabine-induced thrombotic microangiopathy (TMA) is increasingly being recognized, and TTP and HUS are considered disorders on the same spectrum of the disease process [5]. As is known, renal dysfunction tends to be the hallmark of HUS, whereas neurological complications tend to dominate in TTP [6]. 
According to the excellent review by Zupancic et al. [3] on gemcitabine-associated TTP, the complication appears to be dose related and is seen more in individuals with a cumulative dose of $20,000 \mathrm{mg} / \mathrm{m}^{2}$ and when the number of doses exceeds 18 . A review of our patient's chemotherapy records revealed that she had received 13 doses of gemcitabine prior to presentation and that she was in the 8th month of therapy. Usually, the complication is rarely seen before the 7th month of therapy [7]. Of note, however, TTP can be seen earlier in individuals who are on multiple other chemotherapeutic agents associated with the development of the complication. While mitomycin and cisplatin have been classically implicated with TTP, other chemotherapeutic agents are also associated with this complication [8]. Table 2 outlines some of the chemotherapeutic and other classes of drugs associated with the development of TTP.

A very interesting observation seen in patients who develop TTP specifically due to gemcitabine is either the development of new hypertension or difficulty in controlling blood pressure and/or increment in the number of antihypertensive medications in patients who have already been diagnosed with hypertension [9]. In a review of all cases with gemcitabine-associated TMA diagnosed at Partners Healthcare System (Boston, Mass., USA) between January 1997 and February 2002, apparently the patients' blood pressure readings were noted to increase at least one week prior to symptoms onset. Moreover, 3 out of 9 patients had symptoms onset 6-10 weeks after the detection of the elevated blood pressures [9]. Thus, patients on gemcitabine should be frequently monitored for any changes in their blood pressure from baseline, since it may be a predictor of potentially dramatic microvascular complications in the near future. Moreover, in some series, the development of hypertension was also a marker for poor prognosis/outcome [5].

Treatment options employed and outcomes highlighted in the series of case reports have been variable and range from discontinuation of gemcitabine to only the employment of plasmapheresis and use of steroids along with control of blood pressure with antihypertensive medications. Some case reports have also highlighted a potential role of the anti-CD20 antibody rituximab in the treatment of TTP/HUS [8].

Plasmapheresis, however, appears to be the mainstay along with drug cessation in the treatment of gemcitabine-induced TTP, with most patients requiring at least 8-12 treatments. Complications associated with the procedure itself, including line sepsis and hemorrhage from line insertion, thrombosis and mortality documented in patients receiving plasmapheresis should always be kept in mind [10].

\section{Conclusions}

As the indications for the use of gemcitabine increase and its use becomes more widespread, TTP and other disorders on the spectrum of TMAs are important considerations to remember in patients with worsening anemia and thrombocytopenia. New onset or exacerbation of underlying hypertension may provide a clue to diagnose the disease entity earlier in this subgroup of patients. 


\section{Acknowledgements}

We are deeply indebted to the patient and her family for granting us permission to share the case report. Special thanks to Dr. Adam Sohnen for his constant support, guidance and encouragement. Thanks are also due to Dr. Rawad Mounzer (Resident, International Scholars Program), Dr. Jing Zhou Hou (Hematology), Dr. Roy Smith (Hematology), Dr. Ernesto Santos (Interventional Radiology, for his help in the placement of the plasmapheresis catheter), Dr. Eric Gardner (for helping us to perform the lumbar puncture on presentation), and to the excellent care/support shown by the nursing staff, especially by Paul M. Levy, at the UPMC Shadyside Hospital. 
Table 1. Comparison of findings noted in our patient and findings of patients with gemcitabineinduced TTP

\section{Findings in gemcitabine-induced TTP}

New onset or worsening of hypertension noted specifically with gemcitabine-induced TTP; it is thought to represent underlining renal microvascular disease/damage and heralds the onset of TTP in patients treated with gemcitabine

Fever Fever

Neurological symptoms

Microangiopathic hemolytic anemia

Schistocytes present on peripheral smear

Increased LDH

Decreased haptoglobin

Thrombocytopenia

\section{Some degree of renal dysfunction}

Increased $\mathrm{BUN} / \mathrm{Cr}$

Mild proteinuria

Mild hematuria

Fever

\section{Findings in our patient}

Patient did not have any diagnosis of hypertension; noted to have blood pressures as high as 185/94 $\mathrm{mm} \mathrm{Hg}$ on presentation, which increased to $204 / 100 \mathrm{~mm} \mathrm{Hg}$ later during her hospital course, requiring multiple anti-hypertensives

Severe headache and photophobia on presentation

Microangiopathic hemolytic anemia

Schistocytes present on peripheral smear: $1+1-5 \% / \mathrm{hpf}$ Increased LDH: $437 \mathrm{IU} / \mathrm{l}$, increased to $706 \mathrm{IU} / \mathrm{l}$ later Decreased haptoglobin: $<4 \mathrm{mg} / \mathrm{dl}$

Patient's platelet number increased to $266 \times 10^{9} / 1$ in January, and rapidly decreased from $144 \rightarrow 107 \rightarrow 99$ $\times 10^{9} / 1$ prior to the start of plasmapheresis. The lowest platelet number decreased to $37 \times 10^{9} / 1$

Some degree of renal dysfunction BUN increased from $8 \rightarrow 10 \rightarrow 15 \mathrm{mg} / \mathrm{dl}$ despite i.v. boluses and continued hydration; Creatinine level is 1.1 $\mathrm{mg} / \mathrm{dl}$; GFR decreased from 55 to $49 \mathrm{ml} / \mathrm{min} / 1.73 \mathrm{~m}^{2}$. Creatinine worsened to $1.9 \mathrm{mg} / \mathrm{dl}$ during her hospital course

$2+(\sim 100 \mathrm{mg} / \mathrm{dl}$ or $0.5-1 \mathrm{~g} /$ day $)$ protein on dipstick $2+$ (positive) blood on dipstick; 15-20 red blood cells/hpf on microscopy

PT/PTT normal
Fibrinogen normal
Reticulocyte count (unreliable in setting of chemotherapy-induced
TTP; most commonly low)

Increased premature precursors Normal

Normal

Reticulocyte count $0.4 \%$; absolute reticulocyte count $0.010 \times 10^{12} /$ l low

High nucleated red blood cells; $94.4 \%$ neutrophils

Deficiencies of ADAMTS-13 (noted only in 13\% of patients, thereby, representing a different mechanism)

Pulmonary symptoms
94\% (normal $>68 \%$ )

Not present in our patient initially; however, when she received packed red blood cells for her worsening anemia, she developed pulmonary edema (which is also seen in patients with TTP when they receive transfusions. Transfusion-related acute lung injury and acute respiratory distress syndrome may also develop; therefore, patients receiving transfusions need to be closely monitored). 


\begin{tabular}{c|l|l|l}
$\begin{array}{c}\text { Case Reports in } \\
\text { Oncology }\end{array}$ & $\begin{array}{l}\text { Case Rep Oncol 2011;4:143-148 } \\
\text { DOl: 10.1159/000326801 }\end{array}$ & $\begin{array}{l}\text { Published online: } \\
\text { March 16, 2011 }\end{array}$ & $\begin{array}{l}\text { O 2011 S. Karger AG, Basel } \\
\text { ISSN 1662-6575 } \\
\text { www.karger.com/cro }\end{array}$ \\
\hline
\end{tabular}

Table 2. Drugs associated with the development of TTP

\begin{tabular}{|c|c|c|}
\hline $\begin{array}{l}\text { Chemotherapeutic drugs } \\
\text { commonly associated } \\
\text { with TTP }\end{array}$ & $\begin{array}{l}\text { Chemotherapeutic drugs } \\
\text { less commonly associated } \\
\text { with TTP/case reports }\end{array}$ & Other drugs associated with TTP \\
\hline $\begin{array}{l}\text { Mitomycin C (4-15\%) } \\
\text { Cisplatin }(2-6 \%)\end{array}$ & $\begin{array}{l}\text { Fluorouracil } \\
\text { Dacarbazine } \\
\text { Doxorubicin } \\
\text { Carboplatin } \\
\text { Oxaliplatin } \\
\text { Lomustine } \\
\text { Bleomycin } \\
\text { Vinblastine } \\
\text { Medroxyprogesterone } \\
\text { Tamoxifen } \\
\text { Chlorozotocin } \\
\text { Zinostatin } \\
\text { Carmustine } \\
\text { Tretinoin } \\
\text { Pentostatin } \\
\text { Estramustine } \\
\text { Cytarabine } \\
\text { Daunorubicin }\end{array}$ & $\begin{array}{l}\text { Quinine } \\
\text { Estrogen-containing oral contraceptives } \\
\text { Immunosuppressive agents } \\
\text { - Cyclosporine } \\
\text { - Tacrolimus } \\
\text { - Sirolimus } \\
\text { Antiplatelet drugs } \\
\text { - Ticlopidine } \\
\text { - Clopidogrel } \\
\text { Antiviral agents } \\
\text { - Valacyclovir }\end{array}$ \\
\hline
\end{tabular}

\section{References}

1 Hovinga JA, et al: Survival and relapse in patients with thrombotic thrombocytopenic purpura. Blood 2010;115:1500-1511; quiz 1662.

$>2$ Cuttner J: Thrombotic thrombocytopenic purpura: a ten-year experience. Blood 1980;56:302-306.

-3 Zupancic M, et al: Gemcitabine-associated thrombotic thrombocytopenic purpura. The Lancet Oncology 2007;8:634-641.

4 Thachil J: Causes of thrombotic thrombocytopenic purpura. The Lancet Oncology 2007;8:757-758.

5 Izzedine $\mathrm{H}$, et al: Gemcitabine-induced thrombotic microangiopathy: a systematic review. Nephrology Dialysis Transplantation 2006;21:3038-3045.

6 Kremer Hovinga JA, Meyer SC: Current management of thrombotic thrombocytopenic purpura. Curr Opin Hematol 2008;15:445-450.

7 De Smet D, Jochmans K, Neyns B: Development of thrombotic thrombocytopenic purpura after a single dose of gemcitabine. Annals of Hematology 2007;87:495-496.

8 Gourley BL, Mesa H, Gupta P: Rapid and complete resolution of chemotherapy-induced thrombotic thrombocytopenic purpura/hemolytic uremic syndrome (TTP/HUS) with rituximab. Cancer Chemotherapy and Pharmacology 2010;65:1001-1004.

Humphreys BD, et al: Gemcitabine-associated thrombotic microangiopathy. Cancer 2004;100:2664-2670.

10 George JN: How I treat patients with thrombotic thrombocytopenic purpura: 2010. Blood 2010;116:4060-4069. 